\title{
DOOM OR SALVATION? \\ UTOPIAN BELIEFS IN CONTEMPORARY DEVELOPMENT DISCOURSES \\ AND ENVIRONMENTALISM
}

Antje Linkenbach

\begin{abstract}
In the first part of this article I argue that utopian (as well as dystopian) ideas are vital for contemporary global discourses on development and for environmentalism. The utopian element of these discourses - which include mainstream and alternative ones - is deeply rooted in European philosophical, literary and socio-critical traditions, but in its ecotopian form also relates to non-western spiritual and moral thoughts. In the second part I concentrate on the 'environmentalism of the poor', predominant in Third World countries and fundamentally related to livelihood struggles and local ideas of social advancement. I argue that such grass root forms of environmentalism are less involved in imagining a global ecotopia but have become appropriated, interpreted and represented by intellectual elites, media and globally operating activists subsuming them into their own ecotopian imaginaries.
\end{abstract}

\section{HOPE AS CORE ELEMENT OF BELIEF}

Understanding and interpreting 'belief' from a modern Western intellectual perspective involves considering it as opposed to the concepts of knowledge and truth. From this rationalist point of view knowledge requires certitude and correctness, whereas belief implies uncertainty and possibly error. Such a presumptuous classification tends to overlook the fact that belief, in its modern conceptualization, holds a creative, future-oriented and enabling potential.

Two basic elements characterize belief: unrestrained consent to circumstances that are not immediately accessible but can be taken for granted on the basis of the experience and knowledge of a competent witness whom the believer trusts after thorough examination. Accepting such non-accessible circumstances is also possible by per- 
sonally taking over a sensible risk that still has to prove its full truth. Therefore, in contrast to the immediate evidence of assured knowledge the ultimate affirmation of belief has to rely on future probation and fulfilment. This is the intrinsic reason why hope and belief are strongly interconnected. (Lehmann 1973:599; my translation)

Recognizing that hope is deeply connected with belief, we have to reorient our perspective and ask: what is hope? Ernst Bloch defines hope as an emotional condition of human beings. He sees it not as separate from fear, but he claims that hope is superior to fear as it is not passive, like the latter, and it makes people broad-minded instead of confining them: 'The work of this emotion requires people who throw themselves actively into what is becoming...' (Bloch $1986,1: 3)$. Hope is also deeply linked with curiosity, a basic human condition which cannot be domesticated by social rules and regulations and does not allow fantasy to be subdued by the principle of reality. Hope, therefore, may take the form of daydreams or fantasy, but once it becomes conscious it no longer appears as a merely self-based mental feeling but as a utopian function (Bloch $1986,1: 144)$. Hope is the constant anticipation and imagination of a preferred future. José dos Reis speaks of hope as 'transforming utopian consciousness' (2001:48) and Lyman Sargent sees in hope the condition for carving out the space where a better reality can be created (2000:15).

In the following I will argue that utopian (as well as dystopian) ideas are inbuilt in contemporary development discourses and in environmentalism. Firstly, I am going to demonstrate that utopian and dystopian thought is deeply rooted in European philosophical, literary and socio-critical traditions. Secondly, I try to show that post-Word War II utopian/dystopian thought was resurrected in Western countries in the form of the concept of development and in particular types of environmentalism. Thirdly I want to draw attention to the intertextuality as well as the differences between Western discourses on development and environment and those originating in the so-called Third World. Further I want to argue that local discourses and struggles for a self-determined, environmentally sensible development in Third World countries run the risk of being re-interpreted by mediators and advocates who instrumentalize them for their own civilisation-critical ecotopian agenda.

EUROPEAN ROOTS OF UTOPIAN THOUGHT

In 1516, Thomas More wrote a novel titled 'Utopia'. In this novel, a traveller discovers an island where people live in harmony, without private property and monarchy - in all the opposite to English society of those days. More 
invented the term utopia, which is a conflation of two Greek words: eutopos $=$ good place and outopos $=$ no place $($ Kumar 1987:23-24). Utopia is the land which does not exist in reality but where one wishes to live. Yet Utopia is not simply a dream world; as an ideal based on social critique, it has one foot in reality. Its basic premise is that human beings are in principle able to overcome the ills of society - and the utopian literature of the $16^{\text {th }}$ and $17^{\text {th }}$ centuries imagines such ideal places.

Some scholars emphasize that utopia was born with modernity (e.g. Kumar 1991: 51), emerging from Renaissance and Reformation thought and activities. But it is agreed that Utopia has its forbearers. Narratives of Greek and Roman thinkers imagine a 'Golden Age'. However, in contrast to More's utopia, the utopia of Plato, Ovid, and Virgil was situated in the past, in the time of the beginning when humans lived in a perfect stage of happiness. ${ }^{1}$ The Christian concept of Paradise also fits into this pattern, though in its variation as celestial city it is not located in the past but in the future, and it is linked with ideas of the millennium. The millennial Good Time restores something of the glory of the Golden Age, but it is also the End of Time. Therefore eschatology moves utopia into transcendental space and time, locates it in the hereafter, not in the existing world.

Utopia has developed as literary genre, as imaginary fiction, but, while this is its core, other kinds of imagination can also be considered as utopian. Kumar suggests that we 'add to utopia, as an additional or supplementary category, the genre of "utopian theory" or "utopian thought"' (1991:28). Utopian social theory shares the presumption that humanity is perfectible, that human nature and society can be ordered in such a way that it brings about a certain state of material plenty, social harmony and individual fulfilment.

Enlightenment and post-Enlightenment utopian social theory of the $17^{\text {th }}-19^{\text {th }}$ century acknowledges reason and the idea of progress. Henceforth utopia is no longer a place somewhere or nowhere, it is also not located in the hereafter (as in millennial and Christian utopias), but in the future. Utopia is situated within a historical chronology - it is no longer a possible world, but $a$ world to come. Eutopia becomes euchronia - the best time (Kumar 1991:58). The great narratives, like Hegel's philosophy of history, utopian socialism or Historical Materialism - although the latter denies any link to utopianism-envision in history the prime mover towards a perfect state of society, in which human nature can be fully developed, morally and intellectually.

Two themes are prominent in utopian literature and theory between the $17^{\text {th }}$ 
and $19^{\text {th }}$ century. ${ }^{2}$ The first, science and technology, came up in the $17^{\text {th }}$ century in the works of Tomasso Campanella (City of the Sun) and Francis Bacon (New Atlantis), and remained a central topic in Enlightenment and socialist utopias. Science is the thriving power of progress, it is perceived as the source of material abundance that would characterize the free and egalitarian future society. Utopian thinkers are also aware that science means human mastery of nature, adherence to technology and instrumental reasoning (see e.g. Nate 2001:172ff).

The second theme - community and the restructuring of social relations - was not only a thought-experiment but, as an experiment in living, played a vital role in the communitarian movements of the $19^{\text {th }}$ and also $20^{\text {th }}$ century in America and Europe. American movements propagated economic communism but had religious foundations and followed conservative values (Shakers, Rappites etc.; see Kumar 1987: 84f), whereas in England and France socialist utopian communities (for example those founded by Robert Owen and Charles Fourier) experimented with new and liberating forms of work, education, as well as sexual and family relationships.

With the end of the $19^{\text {th }}$ and into the $20^{\text {th }}$ century the anticipatory vision of utopian literature often took the form of anti-utopia or dystopia. The perfected world, still depicted in anti-utopian writings, seemed no longer desirable as it was seen as an inhuman or even anti-human world. One of the most famous dystopian novelists was H.G. Wells, writing at the end of $19^{\text {th }}$ and the beginning of $20^{\text {th }}$ century. In his fiction he painted a society of suppression, imagining scientists as perverted power-mad intellectuals who put science to cruel and inhuman ends (Invisible Man); he warned against the hypertrophy of the merely rational and scientific, against war and technology (The War of the Worlds, The Time Machine). But most well-known are the novels of Aldous Huxley and George Orwell (Brave New World, Nineteen Eighty-Four), which both imagine the use of science to control people's thoughts and actions by a centralised government.

Utopian literature was never completely overruled by its negative counter-pole. H.G. Wells himself wrote novels praising rationality in science and politics (e.g. Men like Gods; The Shape of Things to Come). Scientific utopias got support in the 1920-30s from British scientists and mathematicians, organised in the 'science and society movement'. Amongst them were J.D. Bernal and Joseph Needham. They argued that it is science that can realize mankind's age-old dream of freedom, peace, and plenty.

The belief in science, rationality and the perfectibility of mankind suffered 
a drawback during fascism, Stalinism and World War II, but powerfully reemerged in the 1950-60s. To transform the world into a better place for the whole of mankind was now thought to be a real possibility. In popular writing, utopian ideas revived as science fiction. In social theory and politics, utopia was resurrected 'as the whole system of industrialism and industrial society', dedicated to economic growth and the full realization of the potentialities of science and technology (Kumar 2000:269-60). It was this post-war optimism which allowed the concept of development to emerge, as a universal goal based on an untroubled belief in science and rationality, bringing salvation to the underdeveloped and poverty-stricken people of the Third World.

However, there is another side of the coin. The first decades after WW II were not only a period of development euphoria, but also a period of social criticism, political change and individual liberation in many Western countries. Science and rationality did not remain undisputed. Their destructive potentialities in respect to man and nature were reflected upon in utopian fiction as well as in social sciences, and possible alternatives were looked for. It was in this context that an ecological consciousness arouse, strongly connected with, and stimulated by, studies depicting horror-scenarios of a spaceship earth meeting the limits of its carrying capacity. The 1960-70s saw the production of scientifically based (eco-)dystopias on the one hand and green utopias or ecotopias on the other.

Lucy Sargisson has categorized green utopias explicitly as critical or 'transgressive utopianism' (2001:141) as they break with confining traditions of thought and behaviour and embrace a transformative potential. Utopias are spaces 'in which we can be different', she argues; we can begin to think differently, to explore ideas to their limits and, perhaps, can initiate change. In the same tenor, Krishan Kumar has suggested that we acknowledge the utopian element in contemporary new social movements (1991:101), such as the green movement and the feminist movement, both of which respond to problems of late industrial society. Social movements need utopias, as vision and guideline for action. For the sociologist Karl Mannheim utopia was revolutionary. ${ }^{3}$ Propagated by the dominated, marginalized groups of society, it refuses the existing reality and aims to overthrow it and to build a more favourable world (Mannheim 1960, chapter II, see also Alain Touraine 2000:26).

DEVELOPMENT AS SALVIFIC PROCESS AND PATH TO UTOPIA

Gilbert Rist, one of the most outspoken critics of the post-war development paradigm, declares development a 'religion of modernity', 'secular religion', 
'collective hope, 'collective certainty', and 'social belief' (1997, 19-22). ${ }^{4}$ Jan Nederveen Pieterse (2001) understands development bluntly as a 'secularized version of the Christian perspective' and compares history with a 'salvific process' with redemption as its ultimate goal (2001:25). ${ }^{5}$

Labelling development as 'collective hope' is to unveil development's utopian dimension. In his famous speech given in 1949, which is often said to have inaugurated the development age, US President Truman promised a world of 'peace, plenty and freedom', and 'happiness for all mankind', even for the underdeveloped countries ${ }^{6}$ (Truman in Rist 1997:70). Truman characterized the living conditions of the underdeveloped countries as miserable and pitiable, since nutrition was inadequate, people were victims of disease, and their economic life was primitive and stagnant. It was development which would bring them from hell to heaven, from darkness to light. Walt Rostow in his famous book 'Stages of Economic Growth' (2000) also uses deprecatory categories to describe the 'traditional society' (limited productivity, hierarchical social structure, and long-run fatalism) and promises for those who are ready to give up their old ways of life, a future cockaigne. After 'take-off', development will bring salvation in the form of 'regular growth', helping underdeveloped countries in their 'drive to maturity' and in reaching the 'age of high mass consumption'. Many politicians in Third World countries shared this hope, at least in the first decades after World War II. Development became a realizable utopia, a dream of the 'kingdom of abundance', as Arturo Escobar put it (1995:4).

Why is the analogy of development with belief, religion or even Christianity so important? Rist offers a convincing argument: belief systems, be they Christian or traditional ones, can easily tolerate contradictions (1997:23). In the name of Christ numerous crimes have been committed, but Christians uphold their faith, although they may utter critique. The African Zande never cease to believe in their oracle - if it fails, the sorcerer takes another chicken or otherwise changes the method until he gets the proper result. ${ }^{7}$ Development strategies often lead to complete failure - but the experts and believers, though recognizing the mistakes, do not question development: 'Truth cannot lie, so lies - or mistakes - are always attributed to faulty interpretation, human failings, or lack of information' (Rist 1997: 23). Development 'truth' is even more convincing because development strategies are meant for the benefit of the poor and are based on technology and science. Existing economic and political interests (of the rich) are hidden behind the veils of welfare and objectivity.

While for some, development was (and still is) a promise and achievable utopia others are convinced that development and progress have turned into 'a 
nightmare' (Escobar 1995:4). Critics of development argue that in Third World countries the costs and benefits of development are unequally distributed. While it brought benefit for a few, it did not succeed in poverty reduction for the masses; in many cases development projects even led to environmental destruction, as well as to dispossession, impoverishment and marginalization of those who until then could make a living. I will come back to this later, but at the moment I will concentrate on the wave of social and ecological critique which began to emerge in the West and which was basically concerned with the prospects and future scenarios of the Western industrial society. Here the utopia of progress, economic growth and development created its dystopian counter pole out of which new utopias emerged, imagining possible alternative forms of development, social life and relationship to nature.

\section{THE DYSTOPIAN SCENARIO AND THE EMERGENCE OF ECOTOPIA}

Western ideas of progress and development consider science and technology as preconditions to economic growth. Dystopian critique demonstrates that growth oriented production processes have negative effects on all biological life and the environment. In Silent Spring, published in 1962, Rachel Carson presented the first ecological dystopian scenario. She portrayed a possible world where humans, animals, and plants would suffer due to chemical contamination.

The scientific dystopias, which emerged in the 1960s-70s, are well-known and I will only refer to them briefly. ${ }^{8}$ In 1972, the Club of Rome published its study The Limits to Growth (Meadows et al. 1972). The authors warned that if the current growth trends in world population, industrialization, pollution, food production, and resource depletion remained unchanged, the limits to growth on this planet would be reached within the next one hundred years. About the same time, Barry Commoner, an American biologist, argued in The Closing Circle (1972) that technology would cause the collapse of the environment. Both publications accused the rich and industrialized nations of the world of overusing and depleting resources and thus endangering life on our planet. Other scholars, labelled as environmentalists, imagined overpopulation as the core cause of disaster. In his book Population Bomb (1968) Paul Ehrlich spread the apocalyptic message about too many people on earth, leading to food shortage, deterioration of the environment and nuclear warfare due to competition for resources. To stop population increase states needed to take preventive measures, such as coercive sterilization. In the Tragedy of the Commons (1968) Gerrett Hardin argued that free access to common resources was the greatest obstacle to environmental balance. Users deployed a 'free rider' 
mentality ${ }^{9}$ and with an increase in population, and all users following the same strategy (though rational from an individual point of view), resources would soon be exhausted and degraded. Hardin's suggested remedy was to abandon common resources and introduce private property in farmland, pasturage, and hunting and fishing areas.

Both authors talked about overpopulation as a general problem. However the countries of the Third World, in particular, were made responsible for population increase and the pressure on resources. Some 15 Years later, in 1987, the report on Our Common Future (released by the UN World Commission for Environment and Development) expressed a similar view. Besides the damaging effects of industrialization and technology the report strongly stressed the destructive impact of poverty: 'Poverty reduces people's capacity to use resources in a sustainable manner; it intensifies pressure on the environment ...' (WCED 1987: 49-50; see also WCED in Allaby 1989:244ff). The Report gives an account of destructive practices in the rich and poor countries leading towards a world of disease, toxic waste, and environmental disasters such as deforestation, desertification, climate change, and greenhouse effect.

The WCED report does not stop at picturing a negative future. It presents sustainable development as the magic formula for both 'healing and violating the environment', to put it in the words of Wolfgang Sachs (1992: 29). Sustainable development very clearly reflects a revised perception of the environment; nature is not only seen as something to be exploited (to violate), but, at the same time, as something in need of protection (to heal). ${ }^{10}$ Sustainable development is expected to propel the world and its people from disaster into a better future. Again, development proves its flexibility and effectiveness as belief system and utopian thought. The WCED report as well as the follow-up politics and strategies gave evidence that the rhetoric of sustainability did not necessarily imply a critical stance towards development and the growth-oriented economic capitalist system. Many of those subsumed under the name of environmentalists only argue for a more controlled way of resource exploitation, for less pollution, for the use of alternative energies - because otherwise the global economic system itself would be at risk. Some even wish to increase the mastery of nature, enabling men to control the feedback reactions of the natural system (see below 'the gospel of eco-efficiency').

Critique of the modern world system showed up in ecotopias and ecotopian thought. Literary ecotopias arose in the 1960s, amongst them novels written by Aldous Huxley (Island), Ernest Callenbach (Ecotopia) or Ursula Le Guin (The Dispossessed; The Left Hand of Darkness); they describe societies or 
communities who love and respect nature and enjoy more supportive social relations. The authors got their inspirations from Eastern philosophies (Buddhism), North American Indian culture and 'deep ecologists' (for that term see below). Ursula Le Guin's ecotopia is a (eco)feminist utopia, where equality of the sexes and a nurturing, respectful attitude towards nature go hand in hand.

Literary ecotopias are only part of a more general phenomenon: ecotopian thought emerged in scholarly publications, especially from the economic and social sciences, and in public discourse. An early and very influential approach was the 'ecosophy' of Arne Naess, a Norwegian philosopher who explicitly drew on ideas of Mahatma Gandhi. Naess (1989) distinguishes between 'shallow' and 'deep' ecology. Shallow ecology is aimed to serve the rich as it fights against pollution and resource depletion in order to improve the health and affluence of people in developed nations. Deep ecology has a broader mission; its objective is an alteration of the Western worldview and a restructuring of Western ways of life. Naess' ecosophy rests on two pillars: biocentrism (in contrast to anthropocentrism) - it asks people to regard all life-forms with equal respect; and self-realization - it requires that we transgress conventional knowledge, cultural assumptions and values and create new values and new forms of wisdom. This has to be done by meditative thinking, local government control and intuition about what ought to be. Naess' vision strongly influenced the Green movement in Europe.

The new social movements (especially the green and the feminist movements), ${ }^{11}$ are in their practices and strategies directed at actual socio-economic and political change but have strong utopian elements. Bill Devall and George Sessions argue that ' $[c]$ reating ecotopian futures has practical value. It helps us articulate our goals and presents an ideal which may never be completely realized but which keeps us focused on the ideal. ... [E]cotopian visions help us see the distance between what ought to be and what is now reality in our technocratic-industrial society' (Devall and Sessions 1985: 162). To speak with Ernst Bloch, ecotopias are built on the 'principle of hope'.

Ecotopias challenge the Cartesian dualism of humans and nature (subject and object, mind and matter) as it claims superiority to the human subject and leads to objectification and domination of nature. Ecotopias share certain visions (see Pepper 1996:15ff): they plead for an ecocentric (biocentric) perspective and propagate holistic thinking (including a spiritual dimension). As far as economic, social and political life is concerned, decentralization and selfreliance are the keywords. Small and localized technology is meant to help in (re)gaining control over production processes; smaller, non-hierarchical and 
self-regulating communities are supposed to allow political participation and encourage social responsibility; living in smaller towns and villages is intended to reduce pressure on the environment. ${ }^{12}$ All these notions seek a balance between human beings and nature, they demand respect and reverence for nature, and they demand modesty and limiting material needs. Development is not defined in economic terms but is understood as individual (personal) fulfilment; practices like yoga and meditation are considered to be paths to 'self-development'.

Eco-feminism is part of the green movement, but, by focusing on gender relations it addresses the 'patriarchal project' and so includes an additional dimension. Eco-feminists relate women as life givers to nature and therefore accredit to women a special proximity to and responsibility for nature. Women stand for wisdom, holism, harmony and preservation, whereas men stand for science, dualism, competition and exploitation. It is the aim of the eco-feminist struggle to bring the male and female principles into balance, so that a sustainable and more harmonious world can be created. ${ }^{13}$

Ecotopias emerged in the context of a wider civilization-critical movement which became quite strong in the 1970s in Europe and in the United States. In those days America was engaged in the Vietnam War, Europe lived through the post-1968 phase, and many (young) people had started to criticize conservatism, power politics and war. This, together with a rising ecological consciousness, prepared the ground for a general critique of the Western (American) way of life. The critique was aligned with a search for alternative, more sustainable and more harmonious ways of human existence. Inspiration for that was mainly found in 'primitive' societies and in eastern religious thought. Anthropology at the time (and anthropological 'othering') contributed considerably to the civilization-critical endeavour. From the end of the 1960 os onwards research on hunter-gatherer communities around the world boomed. Among the general public (especially among the younger generation) books on the life and fate of American Indians were popular, fictitious speeches of 'wise native chiefs' from America or the South Pacific were quoted to underline one's own uneasiness with the Western civilization. ${ }^{14}$ In all these academic or popular accounts 'primitive' societies were romanticized as ecologically sensitive and harmonious: In primitive communities people pay reverence to nature, enjoy the warmth and care of social relationships, are not greedy and materialistic but are happy with the fulfilment of their limited needs. A similar message of humility, limitation of worldly desires, and being in tune with nature and the universe was also obtained from the great world religions and philosophical systems of the East, especially Buddhism, Taoism, and Hinduism. Although 
ecotopias do not always and explicitly deal with 'primitive' societies or religion, their imagined futures apparently owe a lot to the civilization-critical discourse of the time.

THIRD WORLD: ENVIRONMENTALISM OF THE POOR

I have so far focused on the utopian element in the mainstream understanding of development, on the dystopian development critique and on ecotopian visions. All of these approaches originated in the West, in the rich and developed countries of the world. But what about the developing countries? Do they have utopian visions comparable to those of the West? Are they concerned in similar ways about humans and nature, about the future of mankind?

Ramachandra Guha makes an argument that " $\mathrm{t}]$ here is a widespread belief that environmentalism is a phenomenon peculiar to the rich nations of the North, a product of the move towards 'postmaterialist' values among the populations of North America and Western Europe' (2000:98). This arrogant 'belief', as we have seen, shows in the earlier scholarly neglect of local conservation practices, it shows in Hardin's claim that people follow a free rider mentality and it still shows in the WCED statement that poverty reduces people's capacity to use resources in a sustainable manner. ${ }^{15}$

Guha and his colleague Juan Martinez-Alier challenge such a view. They make a clear distinction between environmentalism of the 'North'16 and environmentalism of the 'South' (see Guha and Martinez-Alier 1998, Guha 2000, Martinez-Alier 2004). They clearly state that ecological awareness or 'environmentalism' which emerged in the post-materialist and post-industrial society has its particular agendas and they point out two main strands: the 'cult of wilderness' and the 'gospel of eco-efficiency' (or 'managerial ecology'). In a mass-consumer society with enlarged opportunities for leisure, nature becomes a strong focus of attention. The 'cult of wilderness' or 'wilderness environmentalism' is concerned with conservation of nature and its biodiversity for the benefit of man-for scientific, religious, utilitarian reasons, or simply for pleasure. The second current, the 'gospel of eco-efficiency' is not concerned with pristine nature, but with the whole economy; it does not argue against development but focuses on the environmental and health impacts of industry, modern agriculture and urbanisation, and it believes in sustainable development and the sustainable use of resources. Guha and Martinez-Alier then allude to a third strand which arose in the West but did not remain confined to it; it is known under different names: 'environmental justice movement', 'livelihood ecology', 'environmentalism of the poor', or 'liberation ecol- 
ogy' These names cover a diversity of critical discourses and struggles such as the struggle against destruction of local livelihoods, environmental racism and, more recently, bio-piracy. 'Liberation ecology' would also grasp more idealistic discourses and visions seeking ecological and social justice and harmony-discourses I discussed under the heading of ecotopias, although ecotopias are also strongly influenced by the ideology of wilderness.

The form of environmentalism predominantly found in the 'South' is the 'environmentalism of the poor', part of the third current. In all regions of the Third World local livelihoods are under threat as a result of national development projects and industrialization, exploitation and commercialization of natural resources. Local small-scale farmers have to face loss or degradation of their land because of hydroelectric dam and mining projects; forest dwellers and shifting cultivators see encroachment upon their land by settlers and loggers; fishermen are affected by the reduction of their marine resources caused by industrial fishing; commercial timber extraction as well as biodiversity conservation denies local people access to forests and pastures - it would be easy to continue the list. In all cases, destruction of local environments and destruction of local modes of life (or at least: involuntary change) go hand in hand. Development brings violence against humans (society) and against nature. The fight against these threats is taken up by those who are immediately affected: the peasants, the tribes, the fishermen. But their fate has also become of wider concern. Increasingly part of trans-local solidarity networks, local struggles are supported by committed activists, scientists and journalists on a global scale. National and international forms of support are given by Human Rights and Advocacy Organisations aiming to generate publicity by alerting the media and initiating protest campaigns. In many cases, activists, who belong to the educated middle class, have decided to involve themselves in the immediate struggles of local populations.

Destruction of local life worlds often results in political protest, but it also has another consequence. The experience of social and economic disruption and the confrontation with practices informed by materialist ideologies of economic growth, science and progress, force the affected population and their supporters to think creatively about alternative forms of development, find new solutions and initiate social change. Confrontations therefore should not only be perceived as something endangering local people - they may also be enabling. Modernization and development means that local communities are confronted with discourses, practices, structures of power, and ways of life that are basically different from those they are familiar with. This encounter favours a learning process which makes it possible not only to evaluate the 
forms and presentations of modernity, but also to look at one's own society (community, tradition) in a reflexive, distant and sometimes critical way. Once their own way of life loses its self-evident character, people may start to compare different worlds and, if possible, try to consciously decide about the way they want to live.

The environmentalism of the poor involves a vision of the 'good life' or 'preferred future'; ${ }^{17}$ and this vision encompasses care for the local environment and for the community which is part of it. Such a vision is not comparable with a utopian one, as it is firmly grounded in local realities and pragmatically aims for immediate change. However, as a vision it is linked with hope - and hope, as Ernst Bloch says, helps people to 'throw themselves actively into what is becoming' (1986,1:3). It is hope, the optimistic 'belief' in local improvements, the creative anticipation of a better future, which guides people in their struggle for self-determination, in their effort to (re-)gain control over their lives. ${ }^{18}$

LOCAL VISIONS AND GLOBAL ECOTOPIAS - A DELICATE RELATIONSHIP

In many cases, as mentioned above, dedicated individuals of the educated middle class in Third World countries support local claims for social and environmental justice through writing and soliciting public support, or by directly engaging in local protest movements. These educated activists often come from the village or the region involved in a particular conflict, but they may also be committed individuals from an urban context. They often have an academic background in law, natural or social sciences, but they are also well-trained in their own traditions. Being versatile in both modern discursive language and the rhetoric of tradition they are able to translate from one context into the other. They are turned - or turn themselves - into spokespersons and representatives of local protest movements. Local residents often appreciate having spokespersons who are familiar with 'the language of modern ideas' ${ }^{19}$ and who try to bring their issues into the public, to translate their visions, and to establish a dialogue between local residents, environmentalists, activists, and politicians in the endeavour to work together for a better future. In a number of cases local struggles have gained strength, as well as national and international recognition, because of the open and straightforward involvement and support of social activists. ${ }^{20}$

However, there is also the other side to the coin. Writings, speeches and the actions of supportive activists, academics or other intellectuals propel local struggles into the limelight of international environmentalism and make them part of the critical environmental discourse. The way it happens is not always 
or necessarily in favour of the people on the ground. In India, in certain cases the environmentalism of the poor has become appropriated, interpreted and represented by intellectual elites, media and globally operating activists, who harness local struggles to their own interests and fit them into their own political agendas. And even those educated supporters who are involved in the everyday struggles do not bluntly represent the 'authentic' voices of the locals, they are interpreters as well, inclined to speak for others. ${ }^{21}$

Indian environmentalists who are acknowledged in the Western context use a mediatory rhetoric which fits with the post-materialist ecotopian imaginary of the West. 'Mediators' between Indian environmentalism and Western ecotopian strands are forms of spirituality, eco-feminism and the teachings of Mahatma Gandhi.

Eastern religions are a rich source of inspiration for environmentalists in the West and in India. Ecotopias or alternative ways of life are modelled with reference to Buddhism, Taoism, and Hinduism. Buddhism teaches the importance of wisdom, contemplation, moral thought and action; it also says that desire is the main cause of suffering and therefore to stop suffering humans have to control desire. The Taoist concept of Yin and Yang, or the Brahmanic concept of purusa and prakriti, emphasise the unity of opposites (male - female, mind/ intellect - nature). Certain strands of the Indian tradition compare material wealth with the 'real' wealth of fulfillment gained through austerity and simplicity of lifestyle. Accordingly, some educated environmentalists propagate a concept of 'development' which does not relate to material progress but indicates individual happiness, fulfillment and peace. However, local residents fighting for environmental and social justice are not willing to totally abstain from material advancement; they want to improve their lives in a material sense and they formulate their demands respectively.

Eco-feminist utopias in the West argue against the violation and subjugation of nature and women as part of it; they imagine a society based on harmony, equality and respect towards human beings and nature. Indian eco-feminism, propagated chiefly by Vandana Shiva (who is especially famous in Europe and the USA) is concerned about the negative impact mainstream development has on the situation of Indian (especially rural) women. She denounces development as the 'new patriarchal project' (1988). Referring to Hindu textual traditions, which offer a dualism between purusa and prakriti, the male and the female principle, she relates the male to culture / science and the female to nature (with a special affinity to forests). Extrapolating from the Indian struggles for survival, she claims that Indian women are fighting the whole 
ideology and practice of patriarchal society in trying to create a world based on feminist ideology.

Mahatma Gandhi's critique of industrialization and economic growth, of materialism and unlimited production, is well acknowledged in the circles of Western environmentalists, such as in the work of the Norwegian philosopher Arne Naess (see above). In imagining ecotopian society, which cares for nature and social equity, Naess draws heavily on Gandhian ideas of a self-sustained, self-ruled village economy, ${ }^{22}$ it also includes Gandhi's moral claims for modesty and deliberate limitation of physical needs. Many Indian environmentalists take Gandhi's vision as a blueprint for thought and action. ${ }^{23}$ They support local livelihood struggles, but, at the same time, some of them interpret these struggles as the spearhead of a global transformation which they envision in the future. With that they alter the focus of localized struggles for immediate survival and instrumentalize them for their own ideological purposes.

To briefly illustrate the instrumentalization of local environmental struggles for survival I refer to my own research in the Central Himalayan state of Uttarakhand in India (Linkenbach 2007). Uttarakhand consists of two divisions, Garhwal and Kumaon, which came into the limelight in the early 1970s when local residents (men and women) under the leadership of Gandhian activists successfully resisted commercial logging by applying non-violent strategies of protest. The movement became popular under the name of Chipko andolan (hugging-the-trees movement). The main target of the movement was not conservation of nature, but to regain the rights of access to local resourcesrights which had been curtailed by restrictive colonial and postcolonial legislation and national forest policies. For the local population, the right to use their forests to secure local livelihoods included its use in the subsistence sector (as fuel, food, fodder, fertilizer, fibre), but also in small scale industries to obtain monetary income. When the Indian environmentalist discourse gained momentum, educated activists and intellectuals with international reputations reversed the original focus of the struggle and interpreted Chipko andolan as an ecological (conservationist), or even as an eco-feminist, movement. With that they imputed different rationales and different purposes to the local residents engaged in the struggle.

One of the well-known Chipko activists is Sunderlal Bahuguna, an intellectual and committed Gandhian. He rose to international fame and is still recognized as a leading figure in the global ecological or green movement. Bahuguna's position has changed considerably during his lifetime, with regard to both his concept of development and his solutions to the social and political problems 
of montane Uttarakhand.

In 1956 Sunderlal Bahuguna and his wife Vimala, herself a Gandhian social worker, founded an ashram to concentrate on hill development, linking the Gandhian vision of village improvement with Nehru's call for resource utilisation. Bahuguna advocated a moderate form of 'modernization' and national integration through the establishment of welfare programs (education and health care) and local employment schemes, based on the use of natural resources (water and forest) in small scale industries. Whereas Vimala focused on welfare work, especially for women, Bahuguna founded and supported labour cooperatives concentrating on resin extraction and running sawmills.

From the mid-1970s Bahuguna's outlook and activities began to change. At the end of the decade he had completely abandoned the idea of hill-development through forest use and local employment generation. Instead he had become a campaigner for a total ban on tree felling in Uttarakhand. With that, he argued, he was simply representing the 'ecological' view of village women, standing against the 'economic' perspective of village men. Bahuguna started to represent the Chipko movement as an ecological movement, directed only at the conservation of forests: 'in Uttarakhand this movement has created tree-consciousness. The common people have rejected the prevailing notion that tree means timber, they have now realized that trees are for their survival' (Bahuguna 1987a:254). Bahuguna also started to trace Chipko's ideological foundations in Indian religion and spirituality. 'The Chipko is a revolt against the butchery of Nature. It is an attempt to re-establish the values of a ranya (forest) culture by making spirituality the guide of science and technology for the well-being of all living beings' (1987a: 247).

By the 1990s, Sunderlal Bahuguna has made a further shift. He increasingly paid attention to wider social and political problems and in his publications and speeches he provided a critical analysis of the current global situation. ${ }^{24}$ We live in a world of contradictions, Bahuguna states; in our world of plenty, there is poverty, and while we are prosperous, there is dissatisfaction. The cause of that is the materialistic definition of development, the identification of development with economic growth. Besides poverty and hunger, Bahuguna identifies two other global problems or, as he calls them, symbols of our 'perverted society': a war psychosis and pollution. Governments all over the world have failed to solve these problems because all political systems follow the illusion of progress and development which is based on consumerism and the promise of affluence (1992:4-5). But Chipko 'stands to mend these things. It is not simply to save a few trees in [the] Himalayas', Bahuguna proclaims 
(1987b:23).

For Bahuguna, the Chipko movement embodies qualities which pave the way to a new socio-economic and moral order characterized by respect towards human beings and nature, modesty and self-sufficiency. Chipko calls upon the world to redefine development as path to real happiness and fulfilment-for the individual and for the collective.

Like Sunderlal Bahuguna, the above-mentioned Indian eco-feminist and activist Vandana Shiva relates local struggles to global targets. Ecology movements in India are redefining the concepts of development and economic values they are creating a new economics for a new civilization (Shiva 1991:23-24). With reference to Chipko she states:

Chipko's demand is conservation of not merely local forest resources but the entire life support system, and with it the option for human survival. Gandhi's mobilization for a new society in which neither man nor nature is exploited and destroyed, marked the beginning of this civilisational response to the threat of human survival. Chipko's agenda includes carrying forward that vision against the heavier odds of contemporary crises (Shiva 1991:116-117).

\section{CONCLUSION}

This article is concerned about belief in its secular meaning. I argue that belief is deeply connected with hope and, as utopian consciousness, has a transformative potential. Powerful visions and imaginaries have always served as an instrument for criticizing unfavourable current states of affairs by picturing a desirable world to come. The post-Enlightenment period saw the emergence of new utopias predicting technological progress in the service of mankind, but it also brought about dystopias as their counter-pole.

With the Post World War II concept of development and the strong belief in the materialistic, modern rationale, the better world seemed to be within reach - utopia became a real possibility for the West as well as for those parts of the Third World branded as 'underdeveloped. However, economic growth and national development strategies often had disastrous effects on the environment, and also widened the gap between the Western countries and the Third World, bringing about mass consumer society in the West and an extremely unequal distribution of the benefits and costs of development in the South. 
Particular factions in Western societies reacted by criticizing industrialism and the unlimited exploitation of nature, with some critique taking the shape of an apocalyptic vision of the globe moving towards its final stage. However, out of this critical dystopian climate emerged a wave of eco-utopias, asking for a deep-rooted moral and economic transformation of Western society, a shift towards post-materialist values and restoring the lost harmony between humans and nature and within human society.

Post-materialist (green, eco-feminist) utopias, which play an important political role in Western societies, have not progressed in developing countries in the same way. Here they are mainly embraced by critical intellectuals and activists who engage in the global environmental debate and seek recognition in the West. These activists often take on a role as spokespersons for local livelihood-struggles. However, when translating local demands into utopian language they tend to re-interpret and re-shape the 'environmentalism of the poor'.

Those who have been marginalized by development projects are fighting fierce battles to safeguard natural resources as the basis of their everyday livelihoods and a sustainable self-determined way of life. Not lacking a vision for a 'good life' or 'preferred futures', local residents in the Third World are far from nourishing utopian imaginaries in the way they are created in the affluent part of the world. They are not concerned with conservation of nature as such, and they are not concerned with post-materialistic, eco-philosophical or ecofeminist ideologies.

Advocates of local environmental struggles and translators of local demands should beware of instrumentalizing these struggles for a civilization-critical ecotopian agenda, because it deprives these struggles of their particular strength and potential and obscures their targets. Instead, advocates and supporters should try to mediate an open and egalitarian encounter and facilitate dialogue and a mutual learning process in which both sides are willing to listen to each other and to find new forms of collaboration.

NOTES

1 Utopian myths of a golden past are not only confined to the West, they exist also in non-Western cultures.

2 There is a third focus in utopian literature of that time-on sexuality and sexual freedom-which is of marginal relevance in the present context. 
3 Mannheim distinguishes between ideology and utopia. Both ideological and utopian ideas transcend the existing order, but only utopian thought has a revolutionary potential (1960:173-4).

4 Rist refers to Emile Durkheim's concept of religion as 'collective representation' (1997: 20). This concept explicitly excludes the supernatural, the mystical or divinity. Development, subsequently, can be interpreted as a form of secular religion.

5 'Developmentalism and its master plan is not merely a matter of reason and logic, it is also, at heart, the performance of a religious duty, the quest of a utopian rendezvous, the pursuit of a messianistic course.' (Nederveen-Pieterse 2001: 25).

6 In Truman's speech the majority of non-Western cultures and societies representing a diversity of forms and perspectives are categorized as underdeveloped, thus becoming subsumed under a notion that is both homogenizing and pejorative.

7 Rist refers to the well-known work of Evans-Pritchard (1976). The Zande used chickens as their oracles; they fed them poison and the answer to the oracular question (yes or no) depended on the chicken remaining alive or dying.

8 For short biographies of influential early environmentalists see De Steiguer (1997).

9 Economically rational behaviour implies that economic man is driven by personal interest, and tries to maximise profit by exploiting the resources.

10 Ravi Rajan (2008) illustrates how the concepts of stewardship and exploitation of nature became closely related. He takes up the example of 'scientific forestry' which emerged in Germany and France in the $18^{\text {th }}-19^{\text {th }}$ century. Modern scientific forestry 'engendered a new relationship between humanity and the rest of nature'. This new relationship 'was, in effect, a contract with nature. It consisted, in essence, of a quid pro quo - conservation, in exchange for sustained, longterm yield' (2008:53) .

11 The Peace movement is an important element of the new social movements, however, in the present context I concentrate on the green and the feminist movement.

12 See for example Schumacher (1973), Goldsmith (1972), and Gorz (1983). 
13 See for example Carolyn Merchant (2004)

14 See for example Scheurmann (1973), Deloria (1970) and Black Elk (1961).

15 This view dominated although anthropological research has shown that indigenous people are able to care for their environment.

16 They use the expression 'North' to distinguish modern capitalist and (formerly) socialist countries from the 'South', the developing countries or the Third World.

17 This expression was coined by Javeed Alam (1999).

18 These visions often express a preference for the inherited ways of life but include certain advantages of the modern life style (education, health care, controlled participation in the market economy). However, in reality, people often do not have a chance to positively restructure their lives due to eviction from their land and resettlement processes.

19 This expression was coined by Sudhir Chandra (1994).

20 Guha (2000) has named several famous activists of this kind.

21 For a discussion of the problem of interpreting social movements see Linkenbach (1994).

22 In Gandhi's vision the village plays a central role. Here, to Gandhi, the main principles of an ideal social organization are perfectly implemented: self-sustenance, self-reliance and self-rule, based on non-violence and truth. For Gandhi's ideas on village life see Letter to Nehru, in Iyer (1986). Gandhi's vision disregards the actual social hierarchies existing in Indian villages.

23 For Gandhi's role in contemporary environmental discourse and practice see Linkenbach (2008).

24 Bahuguna does not present a 'sociological' analysis and does not argue from an academic point of view. His position is that of a committed social activist, arguing from a moral point of view. 


\section{REFERENCES}

Alam, J. 1999 India: Living with Modernity, Delhi:Oxford University Press.

Allaby, M. (ed.) 1989 Thinking Green: An Anthology of Essential Ecological Writing, London: Barrie and Jenkins.

Bahuguna, S. 1987a 'The Chipko: A people's movement', in M.K. Raha (ed.) The Himalayan Heritage, New Delhi: Gian Publishing House: 238-248.

_ 1987b 'Yes' to life: 'No' to death', in Chipko Information Centre pamphlet, The Chipko Message, Silyara, Tehri Garhwal

1992 People's Programme for Change, New Delhi: INTACH.

Black Elk 1961 Black Elk Speaks, Lincoln: University of Nebraska Press.

Bloch, E. 1986 The Principle of Hope, 3 vols., Oxford: Basil Blackwell.

Carson, R. 1962 Silent Spring, Cambridge: The Riverside Press.

Chandra, S. 1994 'The language of modern ideas: Reflections on an ethnological parable', Thesis Eleven 39:39-51.

Commoner, B. 1972 The Closing Circle: Confronting the Environmental Crisis, London: Cape

De Steiguer, J. E. 1997 The Age of Environmentalism, New York et al.: The McGrawHill Companies.

Deloria, V. Jr. 1970 We Talk, You Listen: New Tribes, New Turf, New York: Macmillan

Devall, B. and Sessions, G. 1985 Deep Ecology, Salt Lake City: Gibbs M. Smith, Inc.

dos Reis, J. E. 2001 'The eternal present of utopianism', in B. Goodwin (ed.), The Philosophy of Utopia, London, Portland, Or: Frank Cass: 44-55.

Ehrlich, P. R. 1968 The Population Bomb, New York: Sierra Club and Ballantine Books. 
Escobar, A. 1995 Encountering Development: The Making and Unmaking of the Third World, Princeton, New Jersey: Princeton University Press.

Evans-Pritchard, E. E. 1976 Witchcraft, Oracles and Magic among the Azande, Oxford: Oxford University Press

Goldsmith, E. 1972 'A blueprint for survival', The Ecologist 2 (1), special issue.

Gorz, A.1983 Ecology as Polititcs, London: Pluto Press

Guha, R. 2000 Environmentalism: A Global History, New Delhi: Oxford University Press.

Guha, R. and J. Martinez-Alier, 1998 Varieties of Environmentalism: Essays North and South, Delhi: Oxford University Press.

Hardin, G. 1968 'The tragedy of the commons', Science 162:1243-1248.

Iyer, R. (ed.) 1986 The Moral and Political Writings of Mahatma Gandhi, Vol.1: Civilization, Politics and Religion, Oxford: Clarendon Press.

Kumar, K. 1987 Utopia and Anti-Utopia in Modern Times, Oxford: Basil Blackwell.

1991 Utopianism, Minneapolis: University of Minnesota Press.

2000 'Utopia and anti-utopia in the twentieth century', in: R. Schaer, G. Claeys and L.T. Sargent (eds.), Utopia: The Search for Ideal Society in the Western World, New York, Oxford: The New York Public Library / Oxford University Press: 251-267.

Lehmann, K. 1973 ‘Glaube’ in: H. Krings, H. M. Baumgartner and Ch. Wild (eds.), Handbuch Philosophischer Grundbegriffe 3, München: Kösel Verlag: 596-605.

Linkenbach, A. 1994 'Ecological movements and the critique of development: Agents and interpreters', Thesis Eleven 39: 63-85.

2007 Forest Futures: Global Representations and Ground Realities in the Himalayas, Ranikhet: Permanent Black. (American ed: London, New York: Seagull, 2007)

2008 'Das erbe Gandhis? Umweltbewegungen in Indien heute' [The Gan- 
dhian legacy: Environmentalism in contemporary India], in: Historische Anthropologie. Kultur - Gesellschaft - Alltag. 16.3 (forthcoming)

Mannheim, K. 1960 Ideology and Utopia: An Introduction to the Sociology of Knowledge, London: Routledge and Kegan Paul.

Martinez-Alier, J. 2004 The Environmentalism of the Poor: A Study of Ecological Conflicts and Valuation, Delhi: Oxford University Press.

Meadows, D. H. et al. 1972 The Limits to Growth: A Report for the Club of Rome's Project on the Predicament of Mankind, New York: Universe Book.

Merchant, C. 2004 Reinventing Eden: The Fate of Nature in Western Culture, New York and London: Routledge.

Naess, A. 1989 Ecology, Community and Lifestyle: Outline of an Ecosophy, translated and revised by David Rothenberg, Cambridge: Cambridge University Press.

Nate, R. 2001, 'Scientific utopianism in Francis Bacon and H.G. Wells: From Salomon's house to the open conspiracy', in: B. Goodwin (ed.) The Philosophy of Utopia, London, Portland, Or: Frank Cass: 172-188.

Pepper, D. 1996 Modern Environmentalism: An Introduction, London and New York: Routledge.

Pieterse, J. N. 2001 Development Theory: Deconstructions/ Reconstructions, London et al.: Sage Publications.

Rajan, S. R. 2008 Modernizing Nature: Forestry and Imperial Eco-Development 1800-1950, New Delhi: Orient Longman

Rist, G. 1997 The History of Development: From Western Origins to Global Faith, London and New York: Zed Books.

Rostow, W. 2000 'The stages of economic growth: A non-communist manifesto' (1960), in R. Timmons and A. Hite (eds.), From Modernization to Globalization: Perspectives on Development and Social Change, UK: Blackwell

Sachs, W. 1992 'Environment', in W. Sachs (ed.), The Development Dictionary: A Guide to Knowledge as Power, London and New Jersey: Zed Books: 26-37 
Sargent, L. T. 2000 'Utopian traditions: Themes and variations', in R.Schaer, G. Claeys ad L.T. Sargent (eds.), Utopia: The Search for Ideal Society in the Western World, New York, Oxford: The New York Public Library / Oxford University Press: 8-17.

Sargisson, L. 2001 'Green utopias of self and other', in B. Goodwin (ed.), The Philosophy of Utopia, London, Portland, Or: Frank Cass:140-156.

Scheurmann, E. 1973 Der Papalagi: Die Reden des Suedseehaeuptlings Tuiavii aus Tiavea. Eine Kritik der Europaeischen Kultur, Verfasst von einem Exoten, Westberlin, Jacobson. [1 $1^{\text {st }}$ ed. 1921] English ed.: Chief Tuiavii and E. Scheurmann 1997 Tuiavii's Way: A South Sea Chief's Comments on Western Society, Toronto: Legacy 1997.

Schumacher, E. F. 1973 Small is Beautiful: A Study of Economics as if People Mattered, London: Blond and Briggs

Shiva, V. 1988 Staying Alive: Women, Ecology and Survival in India, Delhi: Kali for Women.

Shiva, V. in association with J. Bandyopadhyay et al., 1991 Ecology and the Politics of Survival: Conflicts over Natural Resources in India, New Delhi: Sage.

Touraine, A. 2000 'Society as utopia', in R.Schaer, G. Claeys und L. T. Sargent (eds.), Utopia: The Search for Ideal Society in the Western World, New York, Oxford: The New York Public Library / Oxford University Press: 18-31.

(WCED) World Commission on Environment and Development (ed.) 1987 Our Common Future, Oxford et al.: Oxford University Press. 